\title{
Botrytis porri Buchw. on leek as an important storage fungus in Finland
}

\author{
Risto TAHVONEN \\ Department of Plant Pathology, University of Helsinki, \\ SF-00710 Helsinki 71, Finland
}

\begin{abstract}
Botrytis porri Buchw. was found to be a common and economically significant pathogenic fungus on leeks in storage. The increase in the number of fungi caused a linear decrease in the number of marketable leeks when stored at $0.5^{\circ} \mathrm{C} . B$. porri was found to spoil leeks even at $-0.5^{\circ} \mathrm{C}$. Spraying with benomyl and thiophanatemethyl one or two weeks before harvesting significantly decreased the numbers of the fungus and the amount of damage caused during storage. Botrytis allii Munn and Fusarium avenaceum Sacc. rarely caused spoilage of leeks.
\end{abstract}

\section{Introduction}

Leeks come second to onions as important Allium plants in Finland. The area under cultivation has increased from about 30 ha to 80 ha during the 1970 's. The value of the crop is high since the price of leeks is about three times that of onions in Finland. Leeks are stored in the field in more southerly countries, but owing to the severe winter in Finland they have to be moved to temporary stores or refrigerated stores. Although rather extensive studies have been carried out in Finland (SuHONEN 1970) on storage techniques and conditions, diseases occurring during storage have not been studied at all. In practice, however, the most serious risk factor in the storage of leeks has proved to be storage diseases. Rather little research has been carried out abroad on the storage diseases of leek presumably as a result of the specialised cultivation technique required. In Norway, the most important fungal pathogen of leeks in storage has been found to be Botrytis porri Buchw. (ROED 1952). Pathogens are considered to be a serious problem in the storage of leeks in Norway (Hoftun 1978 a).

The aim of this study was to determine the fungal pathogens of leeks in storage, their significance and possible ways of controlling them by means of fungicide sprays before harvesting.

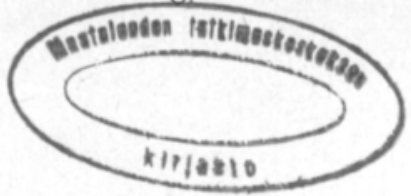




\section{Material and methods}

Storage experiments were carried out in 1975/76, 1976/77, 1977/78 and $1978 / 79$. The stored leeks, variety "Copenhagen marget», were grown each year on the same site in Viikki which had not earlier been used for growing leeks. The seedlings were grown in the greenhouse, planted during the period 15. -25. 5. and the crop harvested during the first or second week in October. The field, which was of good fertility, was given a basic fertilization each year of $1200-1400 \mathrm{~kg} / \mathrm{ha}$ of chloride-free compound fertilizer $\left(\mathrm{N}: \mathrm{P}_{2} \mathrm{O}_{5}: \mathrm{K}_{2} \mathrm{U}=\right.$ $7: 24: 14)$ and nitrogen was added $2-3$ times during the growing season as calcium nitrate to give a total annual nitrogen dosage of $250 \mathrm{~kg} \mathrm{~N} / \mathrm{ha}$.

The leeks were placed in a refrigerated store at $0-+1^{\circ} \mathrm{C}$ and a relative humidity of $96-98 \%$. From 10 to 15 normal-sized leeks per replication were placed in open, perforated (Ø $1 \mathrm{~cm}$, at intervals of $15 \times 15 \mathrm{~cm})$ plastic bags. Before storage, the roots of the leeks were trimmed to a length of about $1 \mathrm{~cm}$ and the leaves shortened by about $1 / 3$.

At the end of the storage period, the fungi on each leek were determined and the degree of fungal infection estimated using the scale $\mathbf{0 - 5}$. The leeks were then prepared for marketing in the normal way. The fungus determinations were carried out using a stereomicroscope. Whenever necessary, plant samples were placed on moist filter paper in petri dishes for more precise determinations and for preparing pure cultures.

Spraying was carried out on the field one or two weeks before harvesting using different types of fungicide. The results of the fungicide experiments carried out during the first two years have not been used because the fungus contents were so low that the effect of the fungicide treatments was insignificant. In the experiments carried out in 1977/78, $20001 /$ ha of a $0.06 \%$ commercial preparation of benomyl (Benlate $50 \%$ ), $0.07 \%$ of thiophanate methyl (Topsin M $70 \%$ ), $0.08 \%$ of captaphol (Difolatan 80 WP $80 \%$ ) and $0.25 \%$ of tolyl fluanide (Euparen M $50 \%$ ) were used. In 1978/79, 1000 1/ha of a $0.12 \%$ commercial preparation of benomyl and $0.14 \%$ of thiophanate methyl were used. The spraying dates are shown in Tables 1 and 2. The amount of fungicide residues on the leeks at harvesting time and in the final year, also at the end of the storage period, was determined at the State Institute of Agricultural Chemistry. In 1977, the plants were sprayed about one month before harvesting with a suspension of Botrytis porri in order to ensure even infection of the crop. Corresponding treatment was not carried out the following year as infection of the crop took place naturally.

The growth of Botrytis porri at different temperatures was studied in 1977/78. A piece of $B$. porri agar was placed on the upper part of a leek which had been cut to a length of about $10 \mathrm{~cm}$. The leeks were stored on damp filter paper in containers covered by plastic film. Eight infected leeks were incubated at each temperature: $-0.5^{\circ} \pm 0.5^{\circ},+1^{\circ} \pm 0.5^{\circ},+4^{\circ} \pm 0.5^{\circ}$ and $+8^{\circ} \pm 1^{\circ} \mathrm{C}$. A similar experiment using leek discs was carried out the previous year. The results of this test will not be discussed here as they were in complete agreement with those obtained in $1977 / 78$. 
Leek samples obtained during the course of the experiments from leek stores situated in different parts of Finland were studied in order to determine the types of fungi which affect leeks in storage.

\section{Results}

Botrytis porri Buchw. on stored leeks

Botrytis porri (syn.: Botryotinia porri (van Beyma) Whetz., Sclerotinia porri van Beyma) produced $9-11 \mu(11.7 \mu)$ thick, initially light coloured, later grey mycelia. Conidiophores and conidia (Fig. 1) were formed on the host

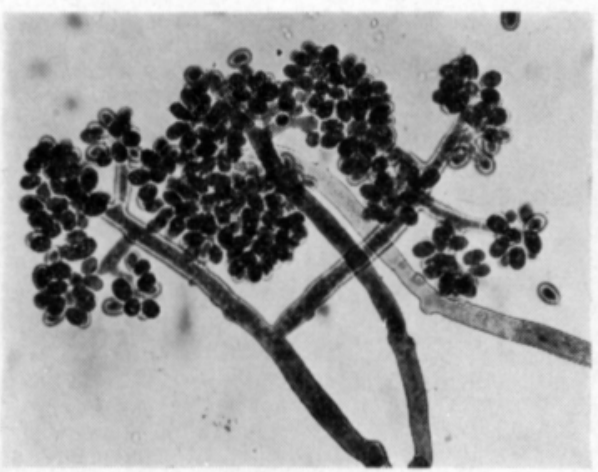

Fig. 1. Botrytis porri, conidiophores and conidia, x 600 .

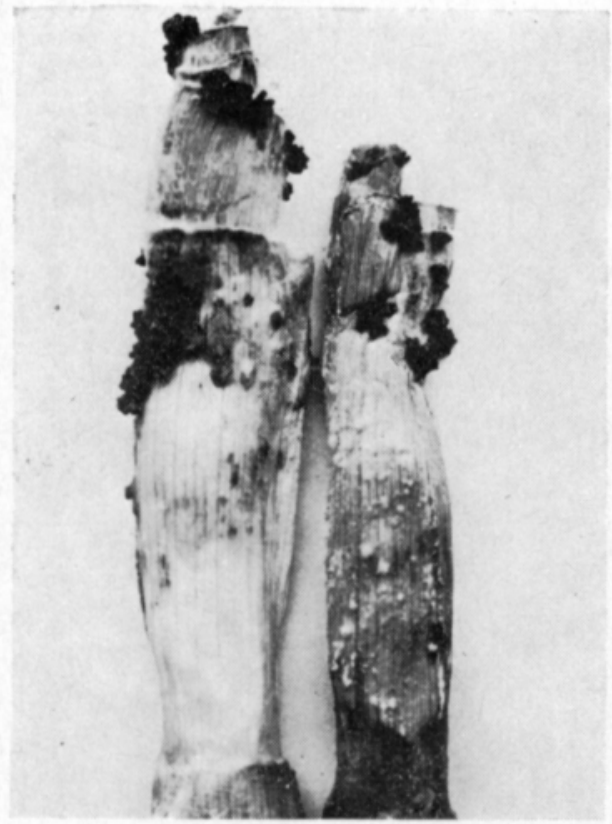

Fig. 3. Sclerotia and mycelia of Botrytis porri in spoiled leeks. Temperature experi -ment.

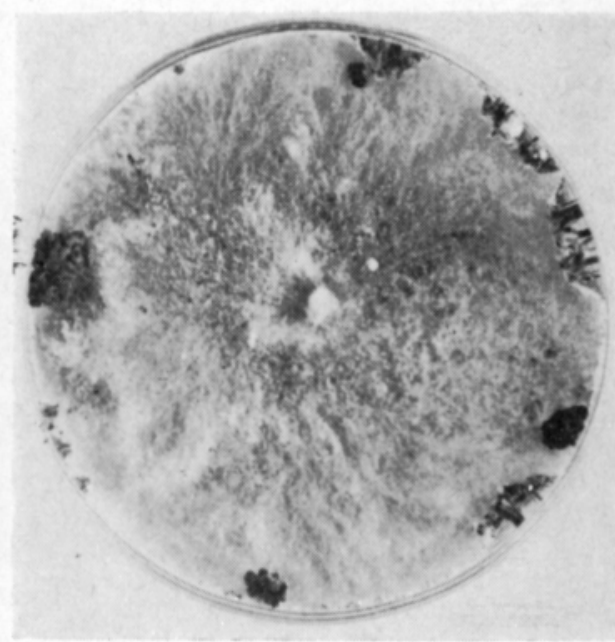

Fig. 2. Six-week old culture of Botrytis porri on PDA medium.

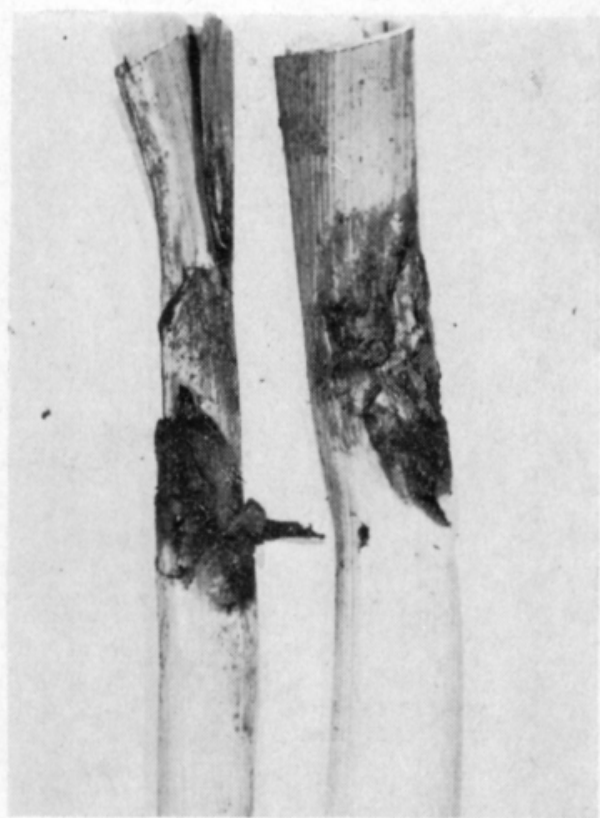

Fig. 4. Serious spoilage on stored leeks caused by Botrytis porri. 
plants, but conidia were not formed at all on potato dextrose (PDA, Difco) agar. The conidia were $11-18 \mu(14.5 \mu) \times 9-12 \mu(10.8 \mu)$ in size. The fungus produced 3-10 $\mathrm{mm}$, irregular-shaped sclerotia on the PDA medium (Fig. 2) and also on leeks (Fig. 3). The sclerotia were initially light grey in colour, but as they aged turned almost completely black. When leeks were stored in the normal way, the plants lying closely packed together, sclerotia were rarely formed. The fungus produced large numbers of sclerotia in the autumn in the field and in the temperature experiments where the leeks were kept separate from each other. The fungus was found in all parts of the leek plants. $B$. porri grew extensively throughout the plant tissues and also grew out between the leaves. The infected plant tissue became soft and watery (Fig. 4). Leeks which were packed tightly together became very slimy and appeared at first glance to have been spoilt by bacteria.

$B$. porri was found in all the areas studied: the Helsinki, Turku and Jyväskylä areas and the Aland Islands. On the basis of discussions carried out with farmers and consultants, it is apparent that the fungus is also to be found in other areas where leeks are cultivated. B. porri was usually found only on leeks which had been stored, but in 1977 and 1978 the disease was already apparent in October on the upper parts of leek plants growing in the field. The fungus did not cause any damage in the field.

At Viikki, where the disease was followed for four years in succession, the fungus occurred in less than $1 \%$ of the leeks during the first year, in about $10 \%$ ot the leeks during the second, and in $80-90 \%$ of the leeks in the next two years. The increase in the amount of $B$. porri in stored leeks brought about a linear $(\mathrm{y}=-0.56 \mathrm{x}+73.8)$ decrease in the marketable proportion of leeks at $0.5^{\circ} \mathrm{C}$ (Fig. 5). After four months storage, a B. porri content of $80-90 \%$ produced almost complete spoilage.

$B$. porri was still able to grow on the leeks at a temperature of $-0,5^{\circ} \mathrm{C}$ and caused a serious amount of spoilage in 4 months (Fig. 6). Raising the temperature to $8^{\circ} \mathrm{C}$ speeded up spoilage.

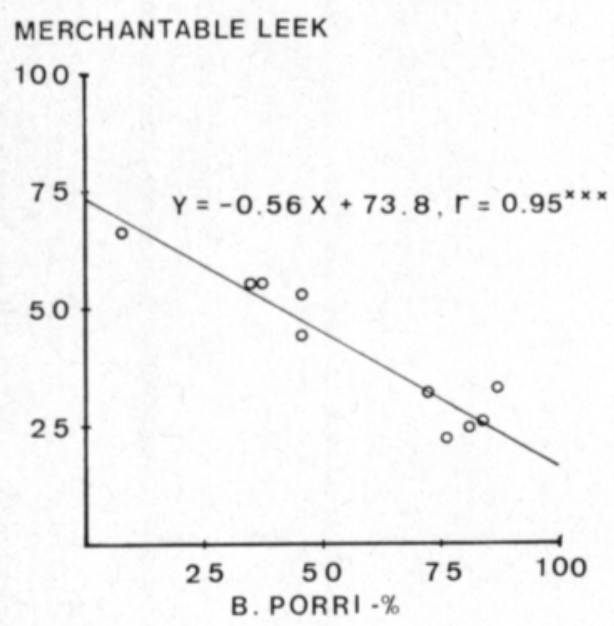

Fig. 5. Effect of Botrytis porri content on number of merchantable leeks after storage for 4.6 months at $+0.5^{\circ} \mathrm{C}$ in $1977-78$. 
Fig. 6. Effect of temperature and storage time on leek spoilage.

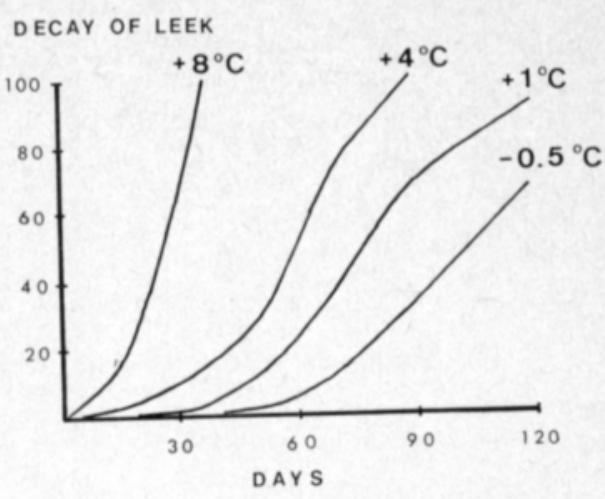

\section{Control of Botrytis porri}

Spraying with benomyl and thiophanate methyl before harvesting significantly reduced the $B$. porri content and also the storage losses (Tables 1 and 2). In $1977 / 78$, when the fungus was artificially spread on the field, two sprayings gave better results than one only. In the last year of the experiment, spraying carried out two weeks before harvesting was as effective as two sprayings, but better than spraying carried out one week before harvesting. The same result was obtained with both preparations. The best treatment reduced the fungus content from about $90 \%$ to about $20 \%$.

Non-systemic control chemicals did not reduce the $B$. porri content of the stored leeks (Table 1).

At harvesting, the amount of fungicide residues present in leeks sprayed two weeks before harvesting with benomyl and thiophanate methyl was always less than $0.4 \mathrm{ppm}$. No residues were found in samples taken at the end of the storage period.

Table 1. Effect of spraying with fungicides before harvesting on the storage resistance of leeks and the degree of Botrytis porri. Harvested 12.10.1977, storage terminated 28. 2. 1978.

\begin{tabular}{|c|c|c|c|c|c|c|}
\hline Control chemical & $\begin{array}{l}\text { Treatment } \\
\text { time, no. } \\
\text { of weeks } \\
\text { before } \\
\text { harvesting }\end{array}$ & $\begin{array}{c}\text { Merchantable } \\
\text { leeks, } \%\end{array}$ & $\begin{array}{l}\text { Completely } \\
\text { spoiled } \\
\text { leeks, } \\
\text { No. - \% }\end{array}$ & $\begin{array}{l}\text { B. porri } \\
\text { content, } \\
\text { No. }-\%\end{array}$ & $\begin{array}{c}\text { Degree of } \\
\text { B. porri, } \\
0-5\end{array}$ & $\begin{array}{c}\text { Residues } \\
\text { ppm }\end{array}$ \\
\hline untreated .............. & & 25.6 & 47.5 & 81.8 & 3.2 & - \\
\hline benomyl ................ & 1 & 55.6 & 17.1 & 37.5 & 1.1 & 0.55 \\
\hline , $\quad$................ & 2 & 44.7 & 22.7 & 46.0 & 1.4 & 0.3 \\
\hline , $\quad$............... & $1+2$ & 66.8 & 1.4 & 8.3 & 0.2 & 1.6 \\
\hline thiophanate methyl & 1 & 53.2 & 10.3 & 46.5 & 1.2 & 0.5 \\
\hline , & 2 & 55.6 & 8.4 & 35.0 & 1.1 & 0.15 \\
\hline tolyl fluanide...... & 1 & 22.3 & 49.1 & 76.8 & 3.2 & 1.8 \\
\hline,$\quad \ldots . .$. & 2 & 26.2 & 45.0 & 84.5 & 3.5 & 0.3 \\
\hline captaphol ............. & 1 & 31.8 & 31.4 & 72.3 & 2.5 & 2.5 \\
\hline ............ & 2 & 33.2 & 41.7 & 87.0 & 3.2 & 0.8 \\
\hline F value $\ldots \ldots \ldots \ldots \ldots$ & & $20.5^{\mathbf{x x x}}$ & $9.7 \times x \times x$ & $21.3 \times x \times$ & $22.2 \times x x$ & \\
\hline $\mathrm{LSD}_{\mathrm{t}_{0.05}} \cdots \cdots \cdots \cdots \cdots$ & & $10.0 \%$ & $16.5 \%$ & $16.6 \%$ & 0.7 & \\
\hline
\end{tabular}


Table 2. Effect of spraying with fungicides before harvesting on the storage resistance of leeks and the degree of Botrytis porri. Harvested 9.10.1978, storage terminated 28. 2. 1979.

\begin{tabular}{|c|c|c|c|c|c|c|}
\hline Control chemical & $\begin{array}{l}\text { Treatment } \\
\text { time, no. } \\
\text { of weeks } \\
\text { before } \\
\text { harvesting }\end{array}$ & $\begin{array}{c}\text { Merchantable } \\
\text { leeks, } \%\end{array}$ & $\begin{array}{l}\text { Completely } \\
\text { spoiled } \\
\text { leeks, } \\
\text { No. - \% }\end{array}$ & $\begin{array}{l}\text { B. porri } \\
\text { content, } \\
\text { No. }-\%\end{array}$ & $\begin{array}{c}\text { Degree of } \\
\text { B. porri, } \\
0-5\end{array}$ & $\begin{array}{c}\text { Residues } \\
\text { ppm }\end{array}$ \\
\hline untreated ............. & & 27.3 & 43.9 & 93.8 & 3.7 & - \\
\hline benomyl ................ & 1 & 53.7 & 3.4 & 36.5 & 1.0 & 0.3 \\
\hline,$\quad \ldots . . . . . . . . .$. & 2 & 57.6 & 3.8 & 19.8 & 0.4 & 0.2 \\
\hline , $\quad$................. & $1+2$ & 56.8 & 4.4 & 18.5 & 0.6 & 0.2 \\
\hline thiophanate methyl & 1 & 56.8 & 7.1 & 41.8 & 1.2 & 0.2 \\
\hline , & 2 & 58.3 & 4.7 & 22.8 & 0.6 & 0.4 \\
\hline - & $1+2$ & 57.9 & 1.0 & 19.0 & 0.4 & 0.5 \\
\hline F value $\ldots \ldots \ldots \ldots . . . . .$. & & $10.6^{\mathrm{xxx}}$ & $7.8^{x x x}$ & $11.6^{\mathrm{xxx}}$ & $12.6^{\mathrm{xxx}}$ & \\
\hline $\mathrm{LSD}_{\mathrm{t}_{0.05}} \cdots \cdots \cdots \cdots \cdots$ & & $10.4 \%$ & $16.4 \%$ & $24.0 \%$ & 0.9 & \\
\hline
\end{tabular}

\section{Other fungi on stored leeks}

Botrytis allii Munn was rarely found in the stored leeks. This fungus causes spoilage of leeks in a similar way to $B$. porri, but owing to its rare occurrence it was of no importance as a storage fungus.

Fusarium avenaceum Sacc. was found on a very few occasions in spoiled leeks. Spoilage always started from the lower part of infected leeks. Infected tissue was red-brown in colour.

In addition to the fungi mentioned above, the following fungi were also found on some of the leeks: Alternaria tenuis auct., Acremoniella atra (Corda) Sacc., Botrytis cinerea Pers., Cephalosporium spp., Chaetomium spp., Epicoccum purpurascens Ehrenb. ex Schlecht., Gliomastix sp., Mucor spp., Papylospora sp., Penicillium spp., Stemphylium botryosum Wallr., Trichothecium roseum Link ex Fries, Typhula sp., Ulocladium consortiale (Thum.) Simmons and Vertilicillium spp. These fungi were only found on the dry and shrivelled outer leaves and were of no importance from the point of view of storage.

\section{Discussion}

In this study, grey mold of leek has been called Botrytis porri Buchw., although in some studies (CRONSHEY 1947, RöEd 1952, CooK 1976) the conidial stage of Botryotinia porri (Van Beyma) Whetz. is considered to be identical to Botrytis byssoidea Walker. B. porri forms large sclerotia on PDA medium (cf. RÖED 1952) but B. byssoidea does not form sclerotia at all on PDA medium (WAlker 1925). BuchWald (1949), Ellis (1971) and Jarvis (1977) consider the conidial stage of Botryotinia porri to be different from B. byssoidea.

$B$. porri was now found for the first time in Finland. As the fungus is an extremely common and damaging storage pathogen of leeks, it has undoubtedly been present in Finland for a long time. It has possibly been confused with B. cinerea Pers., as has occurred elsewhere (RöEd 1952). It may have 
been introduced to Finland along with imported seed as it is also a seed-borne pathogen (NEERGAard 1945). According to the observations made in this study, infection of the crop in the field takes place during the end of summer and autumn before harvesting. The fungus may be already visible, but in most cases it is hidden (cf. Hofrun 1978 b). Continuous cultivation of leeks appears to strongly increase the incidence of the disease.

$B$. porri can grow at temperatures below $0^{\circ} \mathrm{C}$. According to Hoftun (1978 b), it can even take place below $-2^{\circ} \mathrm{C}$. Control of the disease by lowering the storage temperature is therefore not possible. Adding carbon dioxide to the air in the store reduces or inhibits the growth of B. porri (HofTun $1978 \mathrm{~b}$ ), but the construction of storage space in Finland where the air mixture can be controlled, has not become common obviously as a result of the high costs. Control of $B$. porri should therefore be done in the field before harvesting. Spraying the leek plants with benomyl or thiophanate methyl, according to these experiments, effectively controls this fungus (cf. Hoftun 1978 a). The use of these chemicals for this purpose has been approved in Finland in 1979.

\section{REFERENCES}

Соок, R. J. 1979. Sclerotinia (Botryotinia) porri on leeks. Pl. Path. 25: 165

Cronshey, J. F. H. 1947. Sclerotinia porri on Allium spp. in England. Nat. 160: 798.

Ells, M. B. 1971. Dematiaceous hyphomycetes. 608 p. Kew, Surrey.

Hoftun, H. 1978 a. Lagring av purre. I. Verknad av sorter og handsamingmåter i vekst perioden og ved hausting. Meld. Norges Landbr. Högsk. 57, 36: 1-26.

- 1978 b. Lagring av purre. Verknad av temperaturar og luftsamansetnader på vekst av Botrytis porri. Meld. Norges Landbr. Högsk. 57, 39: 1-17.

JARvis, W. R. 1977. Botryotinia and Botrytis species: taxonomy, physiology and pathogenicity 195 p. Monograph 15.

Neergand, P. 1945. General index of 1-10 annual report from the Phytopathological laboratory of J. E. Ohlsens Enke. 22 p. København.

RöEd, H. 1952. Botryotinia porri (Beyma Thoe Kingma) Whetz. on Allium porrum in Norway. Acta Agr. Scand. 2: 232-246.

Sunonen, I. 1970. On the storage Life of the Leek. Acta Agr. Scand. 20: 25-32.

Ms received January 29, 1980. 


\title{
Purjon harmaahome (Botrytis porri Buchw.) merkittävänä purjon varastotautina Suomessa
}

\author{
Risto TAHVONEN \\ Helsingin yliopiston kasvipatologian laitos, Viikki, 00710 Helsinki 71.
}

Tämän tutkimuksen tarkoituksena oli selvittää purjon varastotaudit ja niiden merkitys Suomessa. Tautien on todettu olevan eräs pahimmista haittatekijöistä purjon varastoinnissa. Tautilajistoa ja -määriä tutkittiin eri viljelijävarastoista saaduilla näytteillä ja Viikissä neljänä vuotena suoritetuilla viljelykokeilla. Purjon harmaahomeen kasvuominaisuuksia selvitettiin eri lämpötiloissa ja taudin torjuntamahdollisuuksia tutkittiin ennen sadonkorjuuta tehdyillä torjunta-aineruiskutuksilla.

Purjo harmaahome (Botrytis porri) oli yleisin ja taloudellisesti ainoa merkittävä varastotuhoja aiheuttava sieni purjolla. Se pystyi kasvamaan vielä hieman alle $0^{\circ} \mathrm{C}: \mathrm{ssa}$, joten taudin etenemistä pystyttiin ainoastaan hidastamaan alhaisilla varastointilämpötiloilla. Purjon harmaahome aiheutti runsaana esiintyessään sadon pilaantumisen n. 4 kuukaudessa. Purjon säilyvyys varastossa oli täysin riippuvainen sienen runsaudesta.

Purjo sairastui purjon harmaahomeeseen jo kasvukaudella pellolla. Ennen sadonkorjuuta voitiin kasvien uloimmilla lehdillä havaita sienen aiheuttamia pieniä laikkuja, mutta pellolla ei tapahtunut merkittävää pilaantumista. Ennen sadonkorjuuta suoritettu ruiskutus systeemisillä benomyyli- (Benlate, $1.2 \mathrm{~kg} / \mathrm{ha}$ ) tai tiofanaattimetyyli-valmisteella (Topsin M, $1.4 \mathrm{~kg} / \mathrm{ha}$ ) alensi purjon harmaahomeen aiheuttamia tuhoja varastossa erittäin merkitsevästi. Paras käsittelyaika oli 2 viikkoa ennen sadonkorjuuta. 